University of Nebraska - Lincoln

DigitalCommons@University of Nebraska - Lincoln

USDA National Wildlife Research Center - Staff Publications
U.S. Department of Agriculture: Animal and Plant Health Inspection Service

1999

\title{
Demonstration of Tritrichomonas foetus in the External Genitalia and of Specific Antibodies in Preputial Secretions of Naturally Infected Bulls
}

\author{
J. C. Rhyan \\ US Department of Agriculture \\ K. L. Wilson \\ US Department of Agriculture \\ B. Wagner \\ Western College of Veterinary Medicine \\ M. L. Anderson \\ University of California, Davis \\ R. H. Bondurant \\ University of California, Davis \\ See next page for additional authors \\ Follow this and additional works at: https://digitalcommons.unl.edu/icwdm_usdanwrc \\ Part of the Environmental Sciences Commons
}

Rhyan, J. C.; Wilson, K. L.; Wagner, B.; Anderson, M. L.; Bondurant, R. H.; Burgess, D. E.; Mutwiri, G. K.; and Corbeil, L. B., "Demonstration of Tritrichomonas foetus in the External Genitalia and of Specific Antibodies in Preputial Secretions of Naturally Infected Bulls" (1999). USDA National Wildlife Research Center - Staff Publications. 1061.

https://digitalcommons.unl.edu/icwdm_usdanwrc/1061

This Article is brought to you for free and open access by the U.S. Department of Agriculture: Animal and Plant Health Inspection Service at DigitalCommons@University of Nebraska - Lincoln. It has been accepted for inclusion in USDA National Wildlife Research Center - Staff Publications by an authorized administrator of DigitalCommons@University of Nebraska - Lincoln. 


\section{Authors}

J. C. Rhyan, K. L. Wilson, B. Wagner, M. L. Anderson, R. H. Bondurant, D. E. Burgess, G. K. Mutwiri, and L. B. Corbeil 


\title{
Demonstration of Tritrichomonas foetus in the External Genitalia and of Specific Antibodies in Preputial Secretions of Naturally Infected Bulls
}

\author{
J. C. Rhyan, K. L. Wilson, B. Wagner, M. L. Anderson, R. H. BonDurant, D. E. Burgess, \\ G. K. Mutwiri, and L. B. Corbeil \\ Pathobiology Laboratory, National Veterinary Services Laboratories, \\ US Department of Agriculture, Ames, IA (JCR, $\left.{ }^{1} \mathrm{KLW}\right)$; \\ Department of Veterinary Microbiology, Western College of Veterinary Medicine, \\ University of Saskatchewan, Saskatoon, SK, Canada (BW); \\ California Veterinary Diagnostic Laboratory, University of California, Davis, CA (MLA); \\ Department of Population Health and Reproduction, School of Veterinary Medicine, \\ University of California, Davis, CA (RHB); \\ Department of Veterinary Molecular Biology, Montana State University, Bozeman, MT (DEB); and \\ Department of Pathology, Medical Center, University of California, San Diego, CA (GKM, ${ }^{2}$ LBC)
}

\begin{abstract}
Portions of penis and prepuce were collected from 24 bulls with current or recent Tritrichomonas foetus infection. Epididymides were collected from seven of the bulls, and seminal vesicles and prostate were collected from four. Following immunohistochemical staining with two monoclonal antibodies (34.7C4.4 and TF1.15) prepared against $T$. foetus surface antigens, trichomonads were identified in sections from 15 of the bulls. Organisms were most often located in penile crypts in the midshaft and caudal regions and less often in preputial crypts. Trichomonads were not observed in sections from other genitalia or in subepithelial tissue. $T$. foetus antigen, however, was present in the cytoplasm of some epithelial cells and the cytoplasm of some mononuclear cells in subepithelial lymphoid aggregates and follicles. Preputial smegma was collected from 16 T. foetus-infected bulls and from 16 control bulls with negative T. foetus cultures. Preputial antibody levels to TF1.17, a surface antigen of $T$. foetus, were determined by an enzyme-linked immunosorbent assay. Preputial secretions from infected bulls contained specific antibody of each isotype and subisotype tested. IgG1 responses were the greatest, $\operatorname{IgM}$ and $\operatorname{IgA}$ responses were approximately equal, and $\operatorname{IgG} 2$ responses were low. Each isotype and subisotype response in infected bulls was significantly greater than that in the controls. These results confirm previous speculation concerning anatomical sites of infection and suggest that parasite antigen can be taken up and processed locally, resulting in deposition of specific $\operatorname{IgG} 1, \operatorname{IgG} 2, \operatorname{IgA}$, and $\operatorname{IgM}$ antibodies in the preputial cavity.
\end{abstract}

Key words: Cattle; genitalia; immunity; immunoglobulins; immunohistology; trichomoniasis; Tritrichomonas foetus.

Bovine trichomoniasis, caused by the protozoa Tritrichomonas foetus, is a venereally transmitted infection of cattle that produces early pregnancy loss, occasional pyometra, and, less commonly, mid- to lateterm abortions. Bulls maintain the infection in the preputial cavity and may experience mild transient balanoposthitis. ${ }^{22}$ Although young bulls can become infected, infection rates increase with age, ${ }^{13,32}$ and evidence suggests that bulls $\geq 4$ years of age become persistently infected. ${ }^{23} T$. foetus can be cultured from

\footnotetext{
${ }^{1}$ Present address: National Wildlife Research Center, Fort Collins, CO.

${ }^{2}$ Present address: Veterinary Infectious Disease Organization, Saskatoon, SK, Canada.
}

all regions of the penile and preputial mucosae and occasionally from the urethral orifice. ${ }^{25}$ Highest numbers of organisms have been found on the penile mucosa and adjacent posterior preputial mucosa. ${ }^{18}$

In a previous histopathologic study of naturally and experimentally infected bulls, no lesions could be specifically attributable to $T$. foetus infection. ${ }^{25}$ No organisms were detected in tissue sections by conventional stains or fluorescence microscopy using acridine orange and an immunofluorescent technique that employed a polyclonal antibody against $T$. foetus. $T$. foetus was considered limited to surface secretions in the preputial cavity. In heifers and cows, the organism is found on the endometrial surface and in endometrial glandular lumina. ${ }^{1,26}$ 
Invasion of placental chorion and fetal tissues by $T$. foetus has been demonstrated using conventional stains and immunohistochemical (IHC) techniques. ${ }^{27,28}$ Tissue invasion by other species of trichomonads also has been reported, ${ }^{7,31}$ including prostatic ${ }^{16}$ and cervical ${ }^{17}$ invasion by Trichomonas vaginalis in human beings. This variation in the invasiveness of trichomonads warranted a more detailed study on the location of the organism in the genital tissues of bulls. The bull's local immune response to $T$. foetus infection is poorly understood. Systemic immunization of bulls with trichomonad antigen can prevent or cure infection, ${ }^{11,12}$ yet unvaccinated bulls often remain persistently infected. The purposes of this study were to immunohistologically identify the anatomical sites of $T$. foetus infection in the bull's genitalia, to determine if $T$. foetus antigen crosses the epithelium, and to quantify the local (intrapreputial) antibody responses, by isotype, to the parasite.

\section{Materials and Methods}

Genital tissues from nine bulls from Saskatchewan (Canada) (bull Nos. 1-9), 14 bulls from California (bull Nos. 1023), and one bull from New Mexico (bull No. 24) were used in this study. All bulls were beef breeds, and all were from T. foetus-infected herds. Ages of the bulls ranged from 2 to 6 years. All of the bulls except Nos. 3, 5, 8, and 9 were culture positive for T. foetus at slaughter; Nos. 3, 5, 8, and 9 had been culture positive when tested within 4 months prior to slaughter but were culture negative at slaughter.

Specimens collected at slaughter included portions of the galea glandis, glans penis, shaft of the penis midway between the glans and fornix, prepuce cranial to the fornix, and prepuce just inside the preputial orifice. In addition, portions of the epididymis were collected from bull Nos. 1-3, $7-9$, and 24 , and seminal vesicles and prostate were collected from bull Nos. 7, 8, 9, and 24.

Tissues were fixed in $10 \%$ neutral buffered formalin, routinely processed, embedded in paraffin, sectioned at $4 \mu \mathrm{m}$, and stained with hematoxylin and eosin. IHC staining was done on adjacent sections using a modified technique ${ }^{29}$ that utilizes a commercially available labeled streptavidin-biotin system (Dako, Carpinteria, CA). Paraffin-embedded sections $4 \mu \mathrm{m}$ thick were mounted on positively charged slides (ProbeOn Plus, Fisher Scientific, Pittsburgh, PA), deparaffinized, hydrated to buffer $(\mathrm{pH} 7.5)$, treated with $3 \% \mathrm{H}_{2} \mathrm{O}_{2}$ for 5 minutes to quench endogenous peroxidase, enzyme digested for 6 minutes at $37 \mathrm{C}$ (Proteinase K, Dako), and incubated with one of two monoclonal antibodies (MAbs) developed against $T$. foetus for 20 minutes at $37 \mathrm{C}$. Adjacent sections were treated with the two MAbs, $34.7 \mathrm{C} 4.4^{8}$ and TF1.15. ${ }^{19}$ These MAbs were chosen because each recognizes a surface antigen of $T$. foetus. Each MAb was diluted $1: 500$ with Tris buffer. After three rinses in buffer $(10 \times$ automation buffer, Biomeda, Foster City, CA), sections were incubated with biotinylated goat anti-mouse and anti-rabbit Ig for 10 minutes at $37 \mathrm{C}$. Following three additional rinses in buffer, peroxidase-labeled streptavidin was applied for 10 minutes at $37 \mathrm{C}$. Sections were then rinsed, and the enzyme activity was detected using 3\% 3-amino-9-ethylcarbozole in $N, N$-dimethylformamide (Dako). Sections were counterstained with Gill II hematoxylin (Surgipath Medical Industries, Grayslake, IL) for 3 minutes, rinsed in water, and blued in buffer for 1 minute. Coverslips were mounted with an aqueous mounting medium (Dako). Nonimmunized rabbit Ig was substituted for primary antibody as a negative control. A commercially available capillary gap system (MicroProbe, Fisher Scientific) was used for all IHC staining.

Preputial smegma was collected for antibody analysis from the 14 culture-positive bulls from California plus two more from the same study (16 total). Smegma was also collected from 16 control bulls with negative $T$. foetus cultures. Positive bulls were cultured many times, but negative bulls were only cultured once as part of a previously reported prevalence study. ${ }^{4}$ Because three cultures are recommended to be sure that a bull is negative for $T$. foetus, ${ }^{3}$ some of the negative control bulls may have been false negatives. The samples were collected using a 20 -in. dry plastic uterine infusion pipette attached to a $12-\mathrm{ml}$ disposable plastic syringe. The pipette was introduced into the preputial cavity up to the fornix. Several vigorous back and forth movements with simultaneous negative pressure from the syringe were made to collect each sample. The pipette was removed from the prepuce and the pipette tip was rinsed in $1 \mathrm{ml}$ of phosphatebuffered saline (PBS), $\mathrm{pH}$ 7.2, or lactated Ringer's solution. Samples were frozen at $-20 \mathrm{C}$ until used.

Smegma samples were tested for IgG1, IgG2, IgM, and IgA antibodies to the TF1.17 surface antigen of $T$. foetus by enzyme-linked immunosorbent assay (ELISA) as previously described $^{21}$ with modifications. (MAbs TF1.15 and TF1.17 recognize different epitopes of the same antigen. ${ }^{20}$ ) The TF1.17 antigen was prepared by immunoaffinity purification as previously described. ${ }^{5}$ Half-well microtiter plates (Costar, Cambridge, MA) were coated with $50 \mu \mathrm{l} /$ well of TF1.17 antigen at a protein concentration of $3 \mu \mathrm{g} / \mathrm{ml}$ in $0.1 \mathrm{M}$ carbonate coating buffer, $\mathrm{pH} 9.6$, and incubated overnight at room temperature. The next morning the wells were forcibly emptied, and each was filled with $50 \mu 1$ of $95 \%$ ethanol for 2 minutes. The wells were forcibly emptied again, refilled with ethanol, and incubated for 3 hours at room temperature in a fumehood followed by another 1 hour at $37 \mathrm{C}$. The plates were blocked overnight with $150 \mu 1 /$ well of PBS containing $0.02 \%$ sodium azide (Sigma Chemical, St. Louis, $\mathrm{MO}$ ) and 3\% gelatin (DIFCO Laboratories, Detroit, MI) in a moist chamber at $37 \mathrm{C}$. Wells were washed three times with $150 \mu \mathrm{l} /$ well of PBS containing $0.05 \%$ Tween 20 (PBS$\mathrm{T}$, Sigma). Thawed preputial secretions were centrifuged at $17,500 \times g$ for 5 minutes, and the supernatants were diluted with an equal volume of PBS-T containing $0.3 \%$ gelatin (PBS-T-gel, Sigma). Wells were filled with $50 \mu \mathrm{l}$ of the diluted samples and incubated for 1 hour at $37 \mathrm{C}$. After washing three times with PBS-T, wells were incubated for 30 minutes at $37 \mathrm{C}$ with $50 \mu \mathrm{l}$ of mouse MAbs to bovine IgA, IgG1, IgG2, and IgM (DAS 7, 16, 2, or 11 provided by A. Guidry, US Department of Agriculture, Beltsville, MD) diluted in PBS-T-gel at $1: 4,000 ; 1: 8,000 ; 1: 2,000$, and 1 : 8,000 , respectively. Wells were again washed three times and filled with $50 \mu \mathrm{l}$ peroxidase-conjugated rabbit anti-mouse 
IgG (Zymed Laboratories, South San Francisco, CA) diluted $1: 2,000$ and incubated at $37 \mathrm{C}$ for 30 minutes. The final three washes were done before filling with $50 \mu \mathrm{l}$ of TMB/ hydrogen peroxide substrate (Kirkegard and Perry Laboratories, Gaithersberg, MD) and incubating at room temperature in the dark for 30 minutes. Stop reagent $(0.3 \mathrm{M}$ phosphoric acid) was added ( $50 \mu \mathrm{l} /$ well $)$ and absorbance was read at dual wavelengths (450 and $650 \mathrm{~nm}$ ) on an enzyme-linked immunosorbent assay (ELISA) microplate reader (Molecular Devices, Menlo Park, CA). Negative control wells included antigen but no preputial secretions, and positive control wells contained convalescent serum or vaginal mucus known to have anti-TF1.17 antibodies. Each individual sample was analyzed in duplicate, with mean and standard error reported. For the culture-positive bulls, two samples collected about 6 weeks apart were analyzed in duplicate, with means and standard error reported. The protein content of each was determined by the Bradford method ${ }^{6}$ as performed according to the manufacturer's instructions (BioRad Laboratories, Hercules, CA). Only samples with $>0.2 \mathrm{mg} / \mathrm{ml}$ of protein were included in the analysis.

Differences in ELISA absorbances for preputial secretions of infected or control bulls were analyzed by a one-tailed $t$-test.

\section{Results}

The IHC technique labeled trichomonads in sections from four of the nine Canadian bulls, 10 of the 14 California bulls, and the New Mexico bull. Two of the Canadian bulls found positive by the IHC technique were culture positive at the time of slaughter (Nos. 1, 7), and two bulls (Nos. 5, 8) had been culture positive within the previous 4 months but were negative at slaughter.

The MAb TF1.15 more consistently labeled trichomonads than did MAb 34.7C4.4. Both antibodies used at the 1:500 dilution gave little or no background staining. One unique feature of TF1.15 was that, in addition to labeling trichomonads, it strongly labeled peripheral nerve myelin sheaths. Trichomonads were most often located in penile crypts in the midshaft and caudal regions (14 bulls) and less often in preputial crypts (five bulls). The organisms were typically located in deposits of cellular detritus (smegma) in a few selected crypts (Fig. 1). Only one or two crypts in a section contained organisms, but the same crypts contained clusters of trichomonads in several serial sections from the block. Intact trichomonads were occasionally present two or three cell layers deep in the stratified squamous epithelium of the crypts but were never observed subjacent to the basement membrane. Trichomonads were not seen in the penile or prostatic urethra or in sections of seminal vesicles, prostate, or epididymides.

Inflammatory cell infiltrates were present in the penis and prepuce of all infected bulls and consisted of subepithelial lymphoid nodules with overlying epithelium containing marked lymphoid infiltration, diffuse subepithelial lymphoplasmacytic infiltrates, focal subepithelial and intraepithelial accumulations of neutrophils, and subepithelial perivascular accumulations of lymphocytes, plasma cells, and occasionally eosinophils. Small numbers of neutrophils were occasionally mixed with cellular detritus in penile and preputial crypts. Trichomonads were typically located in crypts lacking inflammatory changes but were also present in some crypts containing neutrophils. Rarely, whole trichomonads were present in the cytoplasm of phagocytes in crypts.

There was diffuse IHC staining of the cytoplasm and/or nucleus of some epithelial cells adjacent to trichomonads, and small granular staining was often present in the cellular detritus surrounding organisms (Figs. 2, 3). In addition, large, active lymphoid follicles with marked mononuclear cell infiltration of the overlying epithelium were present in proximity to some clusters of trichomonads. Fine granules and larger globules of IHC-positive antigen were present in the cytoplasm of rare mononuclear phagocytes located in subepithelial lymphoid nodules or in diffuse subepithelial mononuclear cell infiltrates (Fig. 4). There was no labeling of trichomonads or myelin sheaths in negative control sections treated with nonimmune serum.

Preputial secretions of infected bulls contained antiTF1.17 antibody of each isotype and subisotype tested (Fig. 5). IgG1 responses were greatest, IgA and IgM responses were approximately equal, and $\mathrm{IgG} 2$ responses were very low. In each case, the response in infected bulls was significantly greater than that in the controls (IgG1, $P=0.01$; $\operatorname{IgG} 2, P=0.04$; $\operatorname{IgM}, P=$ 0.04; IgA, $P=0.03)$.

\section{Discussion}

Using the IHC technique, $T$. foetus organisms could be demonstrated in penile crypts of the majority of infected bulls examined. The penile and preputial crypt location is identical to that of Campylobacter fetus, ${ }^{30}$ another motile pathogen that prefers low oxygen tension. Although organisms were present in the superficial layers of epithelium, evidence of invasion of the basement membrane and dermis by intact $T$. foetus was not observed. Trichomonads were not observed in the urethra, epididymis, or accessory sex glands; however, only a small number of these specimens were available for study. The tendency of the organism to colonize only occasional crypts suggests that punch biopsy of penile or preputial epithelium as a method of diagnosis might lack sensitivity.

An unexpected finding was the strong labeling of nerve myelin sheaths by the MAb TF1.15. Previous characterization of the antigen labeled by TF1.15 has shown it to be highly glycosylated ${ }^{19}$ with a glycolipid moiety (B. N. Singh, personal communication). Gly- 


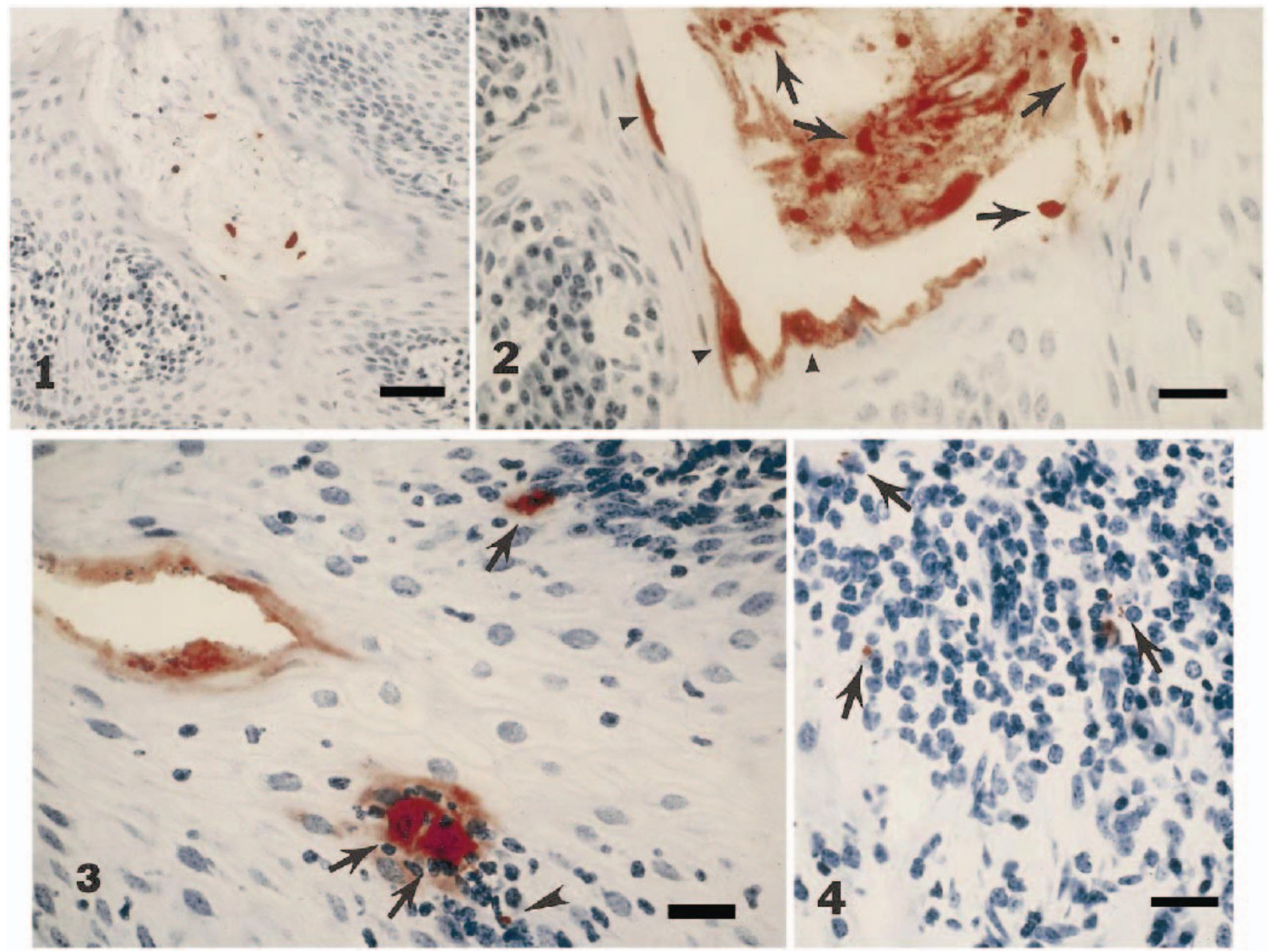

Fig. 1. Penis; bull No. 13. Immunolabeled (red) trichomonads are located in detritus in penile crypt. MAb 34.7C4.4 in labeled streptavidin-biotin-peroxidase method, Gill II hematoxylin counterstain. Bar $=40 \mu \mathrm{m}$.

Fig. 2. Penis; bull No. 13. Note diffuse granular labeling of detritus, identifiable trichomonads (arrows), and diffuse staining of few superficial crypt epithelial cells (arrowheads). MAb 34.7C4.4 in labeled streptavidin-biotin-peroxidase method, Gill II hematoxylin counterstain. Bar $=20 \mu \mathrm{m}$.

Fig. 3. Penis; bull No. 13. There is marked diffuse cytoplasmic staining of few cells (arrows) near the basilar layer of crypt epithelium and focal labeled antigen in the cytoplasm of phagocyte (arrowhead) located subjacent to labeled epithelial cells. MAb TF1.15 in labeled streptavidin-biotin-peroxidase method, Gill II hematoxylin counterstain. Bar $=20 \mu \mathrm{m}$.

Fig. 4. Penis; bull No. 24. Note focal labeling in cytoplasm of few mononuclear cells (arrows) in subepithelial lymphoid nodule. MAb TF1.15 in labeled streptavidin-biotin-peroxidase method, Gill II hematoxylin counterstain. Bar $=15 \mu \mathrm{m}$.

colipids are important constituents of myelin with apparent cross-reactivity to the $T$. foetus surface antigen recognized by TF1.15. MAb TF1.15 labeled trichomonads more consistently than did MAb 34.7C4.4; this finding is consistent with previous work showing that the antigen labeled by MAb TF1.15 is widely conserved in $T$. foetus strains. ${ }^{20}$ A previous IHC study ${ }^{29}$ evaluating MAb 34.7C4.4 demonstrated that the antibody specifically labeled $T$. foetus and only faintly labeled one other trichomonad, Trichomonas gallinae. Other protozoa, bacteria, and fungi were not labeled. In the current study, both antibodies labeled only trichomonads, cells and detritus in proximity to tricho- monads, and peripheral nerve myelin (TF1.15). The staining of cells in proximity to $T$. foetus demonstrates antigen uptake by the cells, and the few stained cells below the epithelium in this area are likely to be antigen-presenting cells. The staining of peripheral nerve myelin was of equal intensity to trichomonad staining, suggesting a specific antibody reaction with cross-reactive epitopes.

Histologic findings in these bulls were consistent with those described previously ${ }^{15,25}$ and were not considered specific for $T$. foetus infection. Subepithelial infiltrates of plasma cells and focal accumulation of lymphocytes and macrophages have been detected pre- 


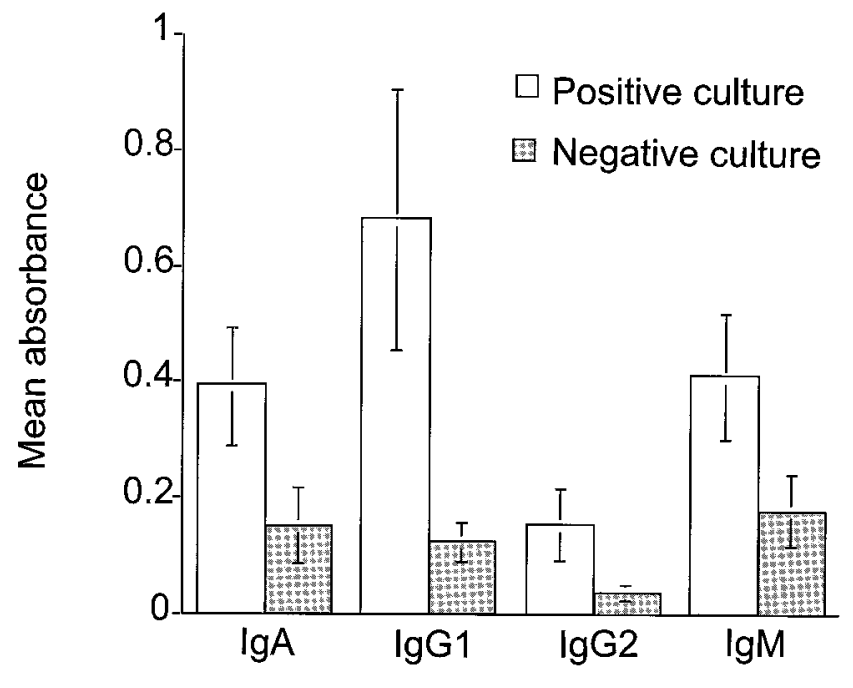

Immunoglobulin isotypes

Fig. 5. Isotypic antibody responses to TF1.17 antigen in preputial secretions of 16 infected and 16 control bulls as determined by ELISA. Bars $=$ mean of duplicate samples \pm standard errors.

viously in the preputial and penile mucosa of bulls with campylobacteriosis ${ }^{30}$ and trichomoniasis. ${ }^{25}$ Even in normal mature bulls, the lamina propria of the preputial and penile mucosa is infiltrated with plasma cells and other mononuclear cells. ${ }^{24,30}$ In a study of 83 bulls, ${ }^{15}$ slightly higher numbers of plasma cells were found in the preputial lamina propria of bulls infected with $C$. fetus or $T$. foetus than in normal bulls. Also observed were lymphoid follicles associated with marked lymphoid infiltration of the overlying epithelium. This "lymphoepithelium" was similar to that found in tonsils. In the T. foetus-infected bulls in the present study, epithelial cells and a few mononuclear cells in subepithelial lymphoid follicles and mononuclear cell infiltrates stained with MAbs to T. foetus antigen, indicating that antigen was taken up by epithelial cells and transmitted to cells below the basement membrane. Because some mononuclear cells in lymphoid follicles are likely to be antigen-presenting cells, the components for inductive sites appear to be present in the lymphoid follicle/lymphoepithelium of the penile and preputial mucosae. The presence of plasma cells in the lamina propria suggests that antibody synthesis and secretion is taking place here also. Thus, the penile and preputial mucosae appear to be both inductive and effector sites.

Immunoglobulins and antibodies found in preputial secretions also suggest that antibody is synthesized in the lamina propria and transported across the epithelium. In previous studies, IgG was generally the most plentiful isotype in preputial secretions, followed by
IgA and then IgM. ${ }^{2,15} \operatorname{IgG} 2$ predominated over IgG1 in older bulls. In neither of these studies were specific antibodies of each isotype measured. Although antibodies were not detected in preputial washings of trichomonal-infected bulls in earlier studies, ${ }^{10,33}$ the preputial secretions may have been more dilute and the detection techniques not as sensitive as those in the present study. High levels of IgG1 antibody to $T$. foetus surface antigen and specific IgA and IgM antibodies were found in the present study, suggesting that the lymphoid follicles under the lymphoepithelium were inductive sites and that the plasma cells in the lamina propria produced these antibodies locally. IgG1 often predominates in bovine secretions such as milk, intestinal contents, and tears, and local synthesis and selective transport have been proposed to explain its presence. ${ }^{9}$ As in other species, IgA is known to be an important secretory immunoglobulin. The relatively high levels of IgM and low IgG2 antibody to TF1.17 antigen in the present study may have been due to the nature of the antigen. TF1.17 is highly glycosylated and monoclonal and polyclonal antibodies to TF1.17 are often IgM. ${ }^{19}$ Furthermore, heifers immunized with TF1.17 antigen produce high levels of serum and vaginal IgG1 but much lower levels of IgG2 antibodies. ${ }^{5,14}$ This tendency of TF1.17 antigen to stimulate IgM and $\mathrm{IgG} 1$ antibodies may explain the low levels of $\operatorname{IgG} 2$ specific antibody.

In a previous study, total immunoglobulin levels in preputial washings were greater in normal bulls than in bulls infected with $T$. foetus, ${ }^{15}$ possibly because of digestion of Ig by the extracellular proteinase of $T$. foetus. ${ }^{34,35}$ The greater levels of IgG1, IgA, IgM, and IgG2 specific antibodies to T. foetus antigen (as opposed to the total immunoglobulins) in infected bulls than in control bulls indicates that local antibody responses to trichomonads do occur during infection. Furthermore, preputial antibody titers to $T$. foetus can be increased by systemic immunization and challenge, ${ }^{10}$ and systemic immunization of bulls can be protective against trichomoniasis. ${ }^{11,12}$

IHC staining for specific antigens of $T$. foetus allowed identification of the anatomical sites of infection and strongly suggested that parasite antigen can be taken up and processed locally. These findings plus the ELISA results show that local antigen processing results in deposition of specific IgG1, IgG2, IgA, and IgM antibodies in preputial secretions. These results encourage further manipulation of the bull's immune response to enhance the effectiveness of immunologic protection at the local level.

\section{References}

1 Anderson ML, BonDurant RH, Corbeil RR, Corbeil LB: Immune and inflammatory responses to reproductive 
tract infection with Tritrichomonas foetus in immunized and control heifers. J Parasitol 82:594-600, 1996

2 Bier PJ, Hall CE, Duncan JR, Winter AJ: Measurement of immunoglobulins in reproductive tract fluids of bulls. Vet Microbiol 2:1-11, 1977

3 BonDurant RH: Diagnosis, treatment and control of bovine trichomoniasis. Compend Cont Ed Pract Vet 7: S179-S188, 1985

4 BonDurant RH, Anderson ML, Blanchard P, Hird D, Danaye-Elmi C, Palmer C, Sischo WM, Suther D, Utterback W, Weigler BJ: Prevalence of trichomoniasis among California herds. J Am Vet Med Assoc 196: 1590-1593, 1990

5 BonDurant RH, Corbeil RR, Corbeil LB: Immunization of virgin cows with surface antigen TF1.17 of Tritrichomonas foetus. Infect Immun 61:1385-1394, 1993

6 Bradford M: A rapid and sensitive method for the quantitation of microgram quantities of protein utilizing the principle of protein-dye binding. Anal Biochem 72:248254, 1976

7 Bunton TE, Lowenstine LJ, Leininger R: Invasive trichomoniasis in a Callicebus moloch. Vet Pathol 20:491494, 1983

8 Burgess DE: Clonal and graphic distributions of a surface antigen of Tritrichomonas foetus. J Protozool 35: 115-122, 1988

9 Butler JE: Bovine immunoglobulins: an augmented review. Vet Immunol Immunopathol 4:43-152, 1983

10 Campero CM, Hirst RG, Ladds PW, Vaughan JA, Emery DL, Watson DL: Measurement of antibody in serum and genital fluids of bulls by ELISA after vaccination and challenge with Tritrichomonas foetus. Aust Vet J 67: 175-178, 1990

11 Clark BL, Dufty JH, Parsonson IM: Immunisation of bulls against trichomoniasis. Aust Vet J 60:178-179, 1983

12 Clark BL, Emery DL, Dufty JH: Therapeutic immunisation of bulls with the membranes and glycoproteins of Tritrichomonas foetus var. brisbane. Aust Vet J 61:6566, 1984

13 Clark BL, Parsonson IM, Dufty JH: Experimental infection of bulls with Tritrichomonas foetus. Aust Vet J 50: 189-191, 1974

14 Corbeil LB, Anderson ML, Corbeil RR, Eddow JM, BonDurant RH: Female reproductive tract immunity in bovine trichomoniasis. Am J Reprod Immunol 39:189198, 1998

15 Flower PJ, Ladds PW, Thomas AD, Watson DL: An immunopathologic study of the bovine prepuce. Vet Pathol 20:189-202, 1983

16 Gardner WA, Culberson DE, Bennet BD: Trichomonas vaginalis in the prostate gland. Arch Pathol Lab Med 110:430-432, 1986

17 Gardner WA, Culberson DE, Stafford JR: Subepithelial organisms in trichomonal cervicitis. Diagn Cytopathol 3: 227-229, 1987

18 Hammond DM, Bartlett DE: The distribution of Trichomonas foetus in the preputial cavity of infected bulls. Am J Vet Res 4:143-149, 1943
19 Hodgson JL, Jones DW, Widders PR, Corbeil LB: Characterization of Tritrichomonas foetus antigens by use of monoclonal antibodies. Infect Immun 58:3078-3083, 1990

20 Ikeda JS, BonDurant RH, Campero CM, Corbeil LB: Conservation of a protective surface antigen of Tritrichomonas foetus. J Clin Microbiol 31:3289-3295, 1993

21 Ikeda JS, BonDurant RH, Corbeil LB: Bovine vaginal antibody responses to immunoaffinity-purified surface antigen of Tritrichomonas foetus. J Clin Microbiol 33: 1158-1163, 1995

22 Jubb KVF, Kennedy PC, Palmer N, ed.: Pathology of Domestic Animals, 3rd ed., vol. 3, pp. 339-367. Academic Press, Orlando, FL, 1985

23 Morgan BB: Bovine Trichomoniasis. Burgess, Minneapolis, MN, 1946

24 Mosaheb MF, Ladds PW: The pathology of the external genitalia of bulls in northern Australia. Aust Vet J 49: 512-516, 1973

25 Parsonson IM, Clark BL, Dufty J: The pathogenesis of Tritrichomonas foetus infection in the bull. Aust Vet J 50:421-423, 1974

26 Parsonson IM, Clark BL, Dufty J: Early pathogenesis and pathology of Tritrichomonas foetus infection in virgin heifers. J Comp Pathol 86:59-66, 1976

27 Rhyan JC, Blanchard PC, Kvasnicka WG, Hall MR, Hanks D: Tissue-invasive Tritrichomonas foetus in four aborted bovine fetuses. J Vet Diagn Invest 7:409-412, 1995

28 Rhyan JC, Stackhouse LL, Quinn WJ: Fetal and placental lesions in bovine abortion due to Tritrichomonas foetus. Vet Pathol 25:350-355, 1988

29 Rhyan JC, Wilson KL, Burgess DE, Stackhouse LL, Quinn WJ: Immunohistochemical detection of Tritrichomonas foetus in formalin-fixed, paraffin-embedded sections of bovine placenta and fetal lung. J Vet Diagn Invest 7:98-101, 1995

30 Samuelson JD, Winter AJ: Bovine vibriosis: the nature of the carrier state in the bull. J Infect Dis 116:581-592, 1966

31 Scimeca JM, Culberson DE, Abee CR, Gardner WA Jr: Intestinal trichomonads (Tritrichomonas mobilensis) in the natural host Saimiri sciureus and Saimiri boliviensis. Vet Pathol 26:144-147, 1989

32 Skirrow SZ, BonDurant RH, Farley J, Correa J: Efficacy of ipronidazole against trichomoniasis in beef bulls. J Am Vet Med Assoc 187:405-407, 1985

33 Soto P, Parma AE: The immune response in cattle infected with Tritrichomonas foetus. Vet Parasitol 33:343348, 1989

34 Talbot JA, Neilsen K, Corbeil LB: Cleavage of proteins of reproductive secretions by extracellular proteinases of Tritrichomonas foetus. Can J Microbiol 37:384-390, 1991

35 Thomford JW, Talbot JA, Ikeda JS, Corbeil LB: Characterization of extracellular proteinases of Tritrichomonas foetus. J Parasitol 82:112-117, 1996

Request reprints from Dr. J. C. Rhyan, USDA, APHIS, VS, Natural Wildlife Research Center, 4101 LaPorte Avenue, Fort Collins, CO 80521 (USA). 